International Journal of Health Sciences
Available online at http://sciencescholar.us/journal/index.php/ijhs
Vol. 1 No. 2, August 2017, pages: $1 \sim 11$
e-ISSN: 2550-696X, p-ISSN: 2550-6978
http://dx.doi.org/10.21744/ijhs.v1i2.25

\title{
Perception of Parents, Teachers, and Nutritionist on Childhood Obesity and Barriers to Healthy Behavior: A Phenomenological Study
}

\author{
(D) crossark
}

I Putu Suiraoka a; Dyah Pradnya Paramitha Duarsa b; I Dewa Nyoman Wirawan c; I Made Bakta d

Article history: Received 5 January 2017; Accepted in revised form 2 July 2017; Approved 10 July 2017; Available online 1 August 2017

\section{Correspondence Author ${ }^{\text {a }}$}

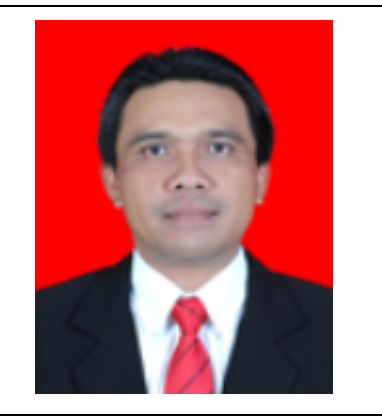

Keywords

Childhood obesity;

Healthy Behavior;

Healthy behavior;

Nutritionist perceptions;

Parents Perception;

\begin{abstract}
The worldwide epidemic of childhood obesity is progressing at an alarming rate. Obesity in childhood at high risk of becoming obese in adulthood and potentially experience metabolic disease and degenerative disease in the future. Obesity is not just an individual problem. It is a population problem and should be tackled as such. Various factors causing obesity in children include children's diet, level of physical activity, family factors, child psychological and genetic factors. This paper attempts to explore the problem more closely by conducting a qualitative study, the main objective of which is to determine barriers to a healthy lifestyle and variables that underlie overweight/obesity in children from their parents perspective. This research is a qualitative research with the phenomenological method. A total of 3 focus group discussions and 7 in-depth interviews were conducted, between July and October 2016, to explore parent's, teacher's, and nutritionist perceptions about underlying factors of their overweight/obesity and barriers to a healthy behavior. The results of this study show: 1) Perception of informants about healthy children is the ideal weight according to age, able to move normally, able to interact socially, and good communication. 2) Perceptions of obesity susceptibility are the wrong diet such as overeating, joy in one type of food and dislike of other foodstuffs, less physical activity and sedentary behavior 3 ). Healthy obstacles in obese children include excessive eating
\end{abstract}

a Medical Doctorate Program of Udayana University Denpasar; Nutrition Department Poltekkes Denpasar suiraoka@gmail.com

b Medical Studies Program S3 Udayana University Denpasar

c Medical Studies Program S3 Udayana University Denpasar

d Medical Studies Program S3 Udayana University Denpasar 
behavior, difficulty controlling healthy eating behaviors, excessive use of $\mathrm{HP} /$ gadgets, computer play, and television viewing, have not found the appeal of exercise and the psychological aspects affecting diet and physical activity. 4) Prevention of childhood obesity includes eating time restrictions, reducing high carbohydrate foods, school canteen cultivation, increasing physical activity of children. Researchers suggest that an obesity prevention program needs to be developed in children by taking into account individual aspects, overcoming environmental barriers and nutrition building in the family and school environment.

e-ISSN: 2550-696X, p-ISSN: 2550-6978(C) Copyright 2017. The Author. SS Journals Published by Universidad Técnica de Manabí. This is an open-access article under the CC BY-SA 4.0 license (https://creativecommons.org/licenses/by-sa/4.0/) All rights reserved.

\section{Contents}

Abstract
1. Introduction
2. Research Method
3. Results and Analysis
4. Conclusion
Acknowledgements
References
Biography of Authors

\section{Introduction}

The worldwide epidemic of childhood obesity is progressing at an alarming rate (Baker, Olsen, \& Sorensen, 2007). Worldwide, the prevalence of combined overweight and obesity rose by $27.5 \%$ for adults and $47.1 \%$ for children between 1980 and 2013 . If this trend continues, more than 70 million infants and children will be overweight or obese by 2025, living mostly in low- and middle-income countries (WHO, 2015).

The prevalence of obesity at age 13-15 years in the Province of Bali of 3.1\% (Badan Litbang Kesehatan, 2010). The prevalence of overweight among 13-15 years old in Indonesia in 2013 is $8.3 \%$ and very obese (2.5\%). Bali Province is one of the provinces with obesity prevalence above national (Badan Litbang Kesehatan, 2013). Obesity in childhood has a high risk of becoming obese in adulthood and potentially experiencing metabolic disease and degenerative diseases in the future (WHO, 2000), (Heird, 2002), (Kasiman, 2011). Childhood obesity is a complex condition, and increases the child's risk for psychological effects, gastrointestinal complications, cardiovascular disease and diabetes as well as the comorbidities of the latter two noncommunicable diseases (NCDs) (WHO, 2015).

An obesity is not just an individual problem. It is a population problem and should be tackled as such. Effective prevention and management of obesity will require an integrated approach, involving actions in all sectors of society (WHO, 2000) The incidence of childhood obesity is strongly related to family variables, including parental obesity, socioeconomic status, parental education, family size and family activity patterns (Berhman, 1999). Various factors causing obesity in children include children's diet, level of physical activity, family factors, child psychological and genetic factors (Damayanti, 2008). In Iran concluded that personal factors are positive perceptions where obesity is normal or even positive, not a barrier to a healthy lifestyle 
of obese adolescents in Iran. Therefore, the individual's perception of obesity is one of the things that affect the incidence of obesity in addition to eating behavior. With the perception of the individual will be aware of the circumstances around him as well as the state of oneself (Amiri et al., 2011).

This paper attempts to explore the problem more closely by conducting a qualitative study, the main objective of which is to determine barriers to a healthy lifestyle and variables that underlie overweight/obesity in child hood from their parents perspective. Understanding these barriers might contribute to existing literature by providing evidence from a different culture, and help to design effective preventive strategies, and implement appropriate interventions.

The question research are: 1) How is the perception of a healthy child? 2) How to worry about childhood obesity? 3) What are the barriers to healthy behavior in obese children? 4) What is the effort in overcoming obesity in children?

\section{Research Method}

This research is a qualitative research with the phenomenological method. A total of 3 focus group discussions and 7 in-depth interviews were conducted, between July and October 2016, to explore parent's, teacher's, and nutritionist perceptions about underlying factors of their overweight/obesity and barriers to a healthy lifestyle. A total of 26 informants consisted of 19 FGD informants and 7 in-depth interviews. Informants in FGDs are parents of obese primary school children. FGD was conducted in 3 elementary schools in Denpasar City. Informant age ranged from 28-56 years with the junior high school to master. Parents' work is quite diverse, ie employees, entrepreneurs, civil servants, and housewives. The informant for the in-depth interview is the teacher and nutritionist.

The researcher contacted each of the potential participants to explain the objectives and the research questions, and if the participant agreed to take part in the research an interview or discussion was scheduled. All the interviews and focus group discussions were conducted in a private room using a semi-structured interview guide. The interview/discussion guide consisted of open-ended questions to allow respondents to fully explain their own opinions, perceptions, and experiences. To begin, each participant was asked to describe his/her own typical day; then they explained their individual perceptions and experiences on "overweight/obesity", the "factors influencing it", "relationship between weight and health" and "effective ways to prevent obesity". During the interviews and focus group discussions, notes were written about the nonverbal signals and the topics they raised. Duration of interviews and focus groups lasted between 60 minutes and 3 hours. Data collection was carried out by the researcher, and audio taped. Then, these records were transcribed verbatim and analyzed consecutively.

Data collection and analysis were done simultaneously according to the grounded theory approach. The interviews and focus group discussions data were analyzed by Open Code 4.02@ Software and were guided by constant comparative analysis.

Differences in coding were resolved via discussions by three independent reviewers. Open, axial, and selective coding was applied to the data. During open coding, each transcript was reviewed several times and the data reduced to codes; codes that were found to be conceptually similar in nature or related in meaning were grouped into subcategories; in axial coding, the aim was to clarify how the subcategories that emerged were related to preliminary categories. Analytical tools, included asking questions and making comparisons, were utilized to find the properties of each concept. When data saturation occurred, interviewing was stopped.

\section{Results and Analysis}

This research was conducted in Denpasar City. The city of Denpasar as the capital of Bali Province is an urban area as well as the center of government, education, economy.

Suiraoka, I. P., Duarsa, D. P. P., Wirawan, I. D. N., \& Bakta, I. M. (2017). Perception of parents, teachers, and nutritionist on childhood obesity and barriers to healthy behavior: a phenomenological study. International Journal of Health Sciences, 1(2), 1-11. https://doi.org/10.21744/ijhs.v1i2.25 


\section{Perceptions about the criteria of healthy children}

Obese children are generally different from other children, they have a larger body size with a larger body mass index. Most parents deny their children are overweight or obese (Moore, 2013). This is reflected in the opinion of parents about the criteria of healthy children, generally, they have nothing to mention about the excess weight.

The parent informant declared the child healthy when his weight was ideal according to his age, but they were unable to reveal how to determine the child's ideal weight. Other informants stated healthy children if the child is not excessive body fat, good appetite, move well, agile move, and regular breaks. Perceptions about child health are also related to social aspects. Children are healthy if they are able to adjust to their environment where they play, study or social environment and able to socialize and good communication. In addition, according to the parent's informants healthy children if rarely ill, or if they recover quickly to pain.

\section{Concerns about Obesity in Children}

Some informants have not been concerned about health problems, although they realize that their children are more obese than other children. According to them his child is agile move and move with his friends. But there are also informants who are already worried about the condition of the child. Worries such as difficulty move, have started lazy to move, and difficult to make certain movements, slow movement and tired quickly when exercising. Another concern is with an appearance as well as susceptibility to certain diseases.

\section{Vulnerability of obesity in children}

Many factors that cause a person susceptible to obesity. Children with certain characteristics and behaviors cause these children to be more prone to obesity. In this study, susceptibility to obesity is related to diet, the pattern of physical and genetic activity. Child diet varies widely, in terms of breakfast habits according to parental informants, there are children who do not breakfast but some always breakfast. But there are some children who just overeat. As one FGD informant revealed :

“...KM breakfast a lot, after eating rice to eating bananas, it runs out apples, it runs out the cereal just left for school..." (Parents, .. 35 y.o.)

“...Kalau KM sarapan banyak sekali, udah makan nasi tapi nggak pernah mie sama telor karena saya larang. Makan nasi, habis makan nasi, pisang, habis itu apel, habis itu sereal baru berangkat sekolah..."

The frequency of eating children is mostly 3 times a day. But the record in this study is their meal time. Some informants stated that feeding time for children is not necessarily the same as in the near future or some others who come home from school rarely eat lunch on the grounds that they have eaten at school. This is a risk to his health because the child who delayed one of the meals would be likely to overeat at the next meal. This disordered eating habit is experienced by some parents because they are not fully able to control their children's eating for work reasons. Sometimes parents give their children the freedom to eat whatever is important they are calm/silent as revealed by one of the FGD informants:

“...But if now especially if we stay working, the important you merely silent important. hard now we are on the one hand we have to work on one side of the world of children yes it's hard especially now that he's big..." (parents, 30 y.o.)

“...tapi kalau sekarang apalagi kalau kita tinggal kerja, yang penting kamu diem aja dah oo yang penting. susah sekarang kita disatu sisi kita harus bekerja disatu sisi dunia anak anak ya itu dah susah apalagi sekarang dia sudah besar..." 
Primary school children eat more often at school. Things that need attention because when we give credence to our children to eat at school there may be two things to note: 1) food for children and 2) the food in the school canteen. The school did not exist that prohibit or require children to bring food to school. School lunches prepared by parents are usually easy to prepare foods. As expressed by the nutritionist informants, based on their observations are generally school lunch food consists of rice and side dishes only. It is rare to add vegetables in school supplies. The reason they do not prepare vegetables in school lunch food is as if filled vegetable say if eaten lunch by a child is unwell again.

Parents informants declare giving money to their children. According to teacher informants, children buy food or eat at break time. There are two scheduled break times, the first break at 9 am and the second rest around $11 \mathrm{pm}$. School children who do not carry lunch will buy in the school cafeteria. Schools restrict children from buying food in the school cafeteria only for safety and hygiene reasons, so they are forbidden to shop out of school. Parents strongly agree with the application of this rule.

Some parents informed their children did not like to eat vegetables. But there are also children who only choose certainly preferred vegetables. In addition to food at home, the same conditions are also found in the school cafeteria. Food sold in the school canteen generally does not include vegetables in the diet. As revealed by one of the nutritionist informants who do school cafeteria coaching, the reason for the food is not quickly stale.

School children are mostly excessive carbohydrate intake. Because of their fondness for noodles, especially instant noodles. Children who have eaten they ask for noodles. One informant stated that breakfast is still common but in the afternoon they always eat noodles plus eggs. There are even children who sulk if not fed noodles. Like the parent informant's statement in the FGD:

“...Kids love noodles filled with eggs. Despite having eaten rice they asked for noodles .. And they can cook their own. I'm not a whole day at home because work so can not control..." (parents, y.o)

“...Mie instan nika pokoknya kalau udah itu.. suka banget dikasi telor gitu biarpun dia sudah makan nasi pak yaa.. abis dah nasi nya satu piring ntarnya itu mak buatin mie klo kita kan aduh nanti aja.. buat mie nya nanti.. dia sudah bisa bikin sendiri pak.. seperti dibilang saya kan ndak seharian full di rumah karena kerja pak.. nahh untuk ngontrolnya itu susah karena sudah bisa bikin sendiri gitu loo.."

Most school children love sweet drinks. In addition, fast food consumption is also high. Even parents make a meal at a fast-food restaurant as a gift on weekends. By reason of having a week does not interact with the child due to busy work. Another cause is the ease of getting fast food because of the large variety of providers of fast food. The development of fast food has been such an extent and touches the layers of society from various economic groups. If the first fast food was only in certain outlets with a limited and famous brand, but now growing well for middleclass economic targets with the availability of fast food shops produced by franchising companies at the local level. Likewise, the target of low economic groups, such as street vendors. Many parents provide school supplies with fast food such as fried chicken, sausage, and nuggets.

The next vulnerability factor is physical activity. Physical activity of school children can be observed from their activities during school and after school. Children have a fairly solid schedule for learning activities. They averaged about 6 to 7 hours per day or 41 hours a week. In addition, they are scheduled to attend tutoring. From learning activities, they sit more and do not move much. Opportunity to play and move only 2 times ie morning break and lunch break. Sports time in school only once a week. Additional physical activity during school is usually on Saturday. School schedules self-development programs every Saturday. In this program, elementary school children perform activities such as dancing, beat gamelan, singing, extra

Suiraoka, I. P., Duarsa, D. P. P., Wirawan, I. D. N., \& Bakta, I. M. (2017). Perception of parents, teachers, and nutritionist on childhood obesity and barriers to healthy behavior: a phenomenological study. International Journal of Health Sciences, 1(2), 1-11. https://doi.org/10.21744/ijhs.v1i2.25 
sports and more.

Physical activity of children can also be observed from the way they go to school. Most children are escorted to school, so they do not do physical activity in walking or cycling. The reasons are among others leaving for work, and the security of children. Physical activity of elementary school children after school usually play bikes, play traditional games and extra sports. However, several informants stated different things, that is, the children spent more time at home. As one informant pointed out that television has greatly indulged them with many of the most favored events by children. Even make them refuse to be asked to do something while being absorbed in watching her favorite show. Others say children watch TV while being assigned to look after their sister. In addition to watching silent television, activity is also done by children who play computer hobby, as revealed by the informant in the FGD

"..Since childhood has been lazy he motion because he hobby is different. Incidentally, at home at home, we do a lot of activity on the computer .. Well he now prefers to play games on the computer..." (parents, 35 y.o)

(“...Yaa memang dari kecil karena gini pak, memang dari sebelum sekolah nika sudah males dia gerak karena dia hobby nya nika lain. Kebetulan kan di rumah kita di rumah kan aktivitasnya banyak yang di komputer .. Nah dia sekarang senengnya juga gitu, main game di komputer itu aja senengnya...")

According to informants, obese children are hard to tell for physical activity. Even become one of the parent complaints that is difficult to get up early, and there is also a declared his son difficult to move besides that they are difficult to control their children to move.

\section{Barriers to Healthy Behavior}

Quite a lot of things to complain about the obstacles experienced when applying a healthy diet in obese children. Among other things: the difficulty stop eating to their children, parents do not have the heart if their children do not eat, and appetite, frequency and excessive eating children. On the other hand, parents are also happier if their children already want to eat. This will certainly be an obstacle in instilling a healthy diet in children.

Obese children often feel hungry at night resulting in overeating. Some parents have difficulty controlling overeating in children. Children also imitate the behavior of their parents as if they were eating a meal if their parents ate at night after work.

Barriers to healthy eating behavior are difficulty controlling children's eating, overeating, the influence of information received by children who build their perception of food. Children get the effect of television ads about snacks that affect the child choosing food snacks. Parents' informants said they could not control what snacks their children ate during school. Another dietary barrier is an overabundance of a certain kind of food. For example noodles, beverage packaging or cereal.

Children's obstacles to physical activity, recognized by some parental informants, indeed they are very less physical activity. Some parents complain that children are hard to put to work and prefer to play mobile (HP) / gadget. But there were also parents that just give the kid play HP/gadgets with the reason they do not want to be disturbed or many activities when these children do chores or homework. So they are even more sent her children to googling, so look for the answer on the internet and the use hp or gadget. Another parent informant said that their child is lazy to move. The children were quick to complain when tired of exercising. Other parents expressed informant children have difficulty attending sporting events and did not find the attraction of sports activities. Obstacles to physical activity are also felt in school. Especially schools that have a narrow yard and no sports field near the school.

One of the obstacles felt by parental informants who inhabit in applying a healthy lifestyle is the behavior of children if they are less eating. Obese children are stunned, emotionless and 
angry if they are hungry. But do not dare to convey to her parents maybe because their parents never limit their eating, like the following quote:

"In a hungry position to disturb his emotions so he is sensitive, quick to get angry .. if a little bit nervous and it upsets his emotions, If I ask, are you hungry? He answered yes .. but afraid to say. Because we do not allow dinner, so she's afraid to say it." (parent, 38 y.o).

“...dalam posisi lapar mengganggu emosinya jadi dia sensitif, jadi dia kalau diganggu jadi kalau dia lapar emosinya terganggu.. yaa cepet marah gitu kan .. trus kan dia suka belajar .. jadi kalau kesenggol dikit marah kesenggol dikit marah mengganggu emosinya, kadang-kadang saya tanya, kakak lapar? Iyaa.. tapi takut karena kita larang makan malam kan, jadi takut dia bilangnya, tetapi kita tahu oo anak ini lapar..."

Psychological factors that cause children to not want to apply a healthy diet or pattern of activity is their attitude when mocked by friends. Some parental informants say children are okay and still normal when teased by friends, so even if ridiculed they are not a problem. But some children have started to appear shame when mocked by his friend, they tend to fight or cry.

\section{Efforts to instill healthy behavior}

Knowing their children are overweight, parents try to control their children's weight. Some parents say they have tried to regulate the diet of their children, such as by reducing food intake. But they are not entirely limiting because the children's considerations are still in its infancy. Another informant stated one attempt is to reduce the intake of carbohydrates, by giving the fruit. There are also parents who limit their dinner. They arranged the last meal time at six o'clock.

The school cafeteria is one of the factors that influence the planting of healthy eating behavior for school children. Because most of them rely on food served in the school cafeteria as a source of energy intake and nutrients. So if the cafeteria is healthy and provides food that suits the needs of school children it will give a good impact. On the contrary, if the school canteen is unhealthy and provides poor food, the nutrient content will not be good. The school cafeteria in Denpasar City has been largely built by the Public Health Center, the Health Office and the BPOM (Drug and Food Agency). The frequency of coaching is usually done once a year. In school cafeteria development, the aspects that are fostered include food sold in canteen and food handlers. In addition to external guidance, the school has also tried to supervise the canteen at school.

One effort to inculcate healthy living behaviors in schoolchildren and especially in overweight and obese children is to increase their physical activity. Some parents claim that they are trying to increase the physical activity of children by asking them to ride bikes or walk when tutoring. They allow to ride a bike or walk generally because the place is not too far from home. While some other parents increase the activity of children with dancing activities and also beating instruments. This cultural-related activity is generally performed in the afternoon with a frequency of three times a week.

\section{Discussion}

Most parents do not admit their child is overweight or obese (More, 2013). Mc.Kenzie et al. (2007) Stated that many people may feel enjoying a healthy condition, although others may view the condition as an unhealthy condition. The expression of informants about healthy condition almost approached the healthy sense according to Health Act no. 36 / 2009, the health includes 4 aspects, namely: physical (body), mental (soul), social, and economic.

Suiraoka, I. P., Duarsa, D. P. P., Wirawan, I. D. N., \& Bakta, I. M. (2017). Perception of parents, teachers, and nutritionist on childhood obesity and barriers to healthy behavior: a phenomenological study. International Journal of Health Sciences, 1(2), 1-11. https://doi.org/10.21744/ijhs.v1i2.25 
Some parents have not shown concern over their children's overweight problems. Because they still see their children agile move and move with other friends. This is in accordance with the theory of health belief model (HBM) in which informants have not understood or feel the serious consequences of obesity. HBM theory states that individuals will perform health behavior based on perceptions of the threat of health problems. Feelings of threat or worry arise from the perception that individuals are vulnerable to health problems and these problems can lead to serious consequences (Rosenstock, 1990, cit. Glanz et al., 1997).

But some informants began to worry about the condition of their child. Forms of concern, among others, children are hard to move, have started lazily to move, slow movement and began to difficult to make certain movements. Another concern is related to appearance. Fear of obesity is also felt in schools, such as lack of learning appetite and in terms of achievement is also said that rarely a child of smart obesity. The condition of obese children is also worrying the teachers when they exercise. Because obese children quickly feel fatigue during exercise. Another form of concern is obese children susceptible to disease. This is consistent with Sharif's assertion that obese children tend to have elevated blood pressure and heart rate, about $20-30 \%$ have hypertension. (Syarif, 2003).

The main cause of obesity in children other than genetic factors is the balance of energy intake and other nutrients with its use by the body. Intake of energy and other nutrients is influenced by diet while energy usage is described with physical activity pattern. This is not in accordance with the recommended balanced nutrition where food intake should come from a variety of foodstuffs so as to meet the nutritional needs. The habit of just liking one or two specific foods is an unhealthy habit (Soekirman et al., 2006). Some school children are very difficult to consume vegetables. Riskesdas research results show that the population of Denpasar, as much as $\mathbf{9 7 . 3 \%}$ consumption of fruit and or vegetables are still lacking (Badan Penelitian dan Pengembangan Kesehatan, 2008). Excess carbohydrate consumption is caused because the child is very fond of noodles and also sweet drinks and fast food. The high consumption of fast food is due to the ease of obtaining and the many variations of fast food providers themselves. Mahdiah (2004) states that obese teenagers consume fast food 2-3 times more often than non-obese ones. As many as $50 \%$ obese children in the city of Denpasar often consume fast food (Eka Padmiari, 2002). An increase in the percentage of portion sizes and intake energy of children in the United States by consuming fast food and drinks with sugar sweeteners (Nelson, Carpenter, \& Chiasson, 2006).

School children are mostly inactive because of the length of time their learning activities and less activity during the home. Children who lack physical activity show a strong relationship with weight gain (Cooper, Page, Foster, \& Qahwaji, 2003). As many as 19\% of children spend more than 2 hours per day watching television or in front of the screen will experience overweight (Fisher, Fraser, \& Alexander, 2006). As much as $43.1 \%$ of the population of Denpasar less physical activity (Badan Penelitian dan Pengembangan Kesehatan, 2008). Obese children tend to be difficult for physical activity. The time spent by children to do physical activity decreases with the increasing time spent on sedentary activities (Nelson et al., 2006).

Some of the obstacles that are experienced related to diet are: difficulty stop eating to children and do not have the heart if their children do not eat. Some informants stated their children's appetite is good, they tend to eat with frequency and excess portion. On the other hand, parents are more pleased if their children already want to eat. This will certainly be an obstacle in instilling a healthy diet. Overweight is experienced because children often feel hungry at night and children who follow the behavior of their parents eat at night after work. Subardja (2004) states that in children who are obese, their absolute metabolism increases with increasing body size, this causes obese children always feel hungry and eat more than normal children.

The obstacles to a healthy diet in children are also experienced by parents is difficult to control the feeding of their children. Parents do not know what their children eat because they work. The selection of food by the child is shaped by that information and builds the child's perception of food. Food consumption at highest risk percentage in Denpasar City. Percentage of 
consumption of fatty foods $27.1 \%$ and food with flavor 95.2\% (Badan Penelitian dan Pengembangan, 2010). Consumption of risky food is said to be frequent if eating foods at risk one or more times per day. In addition, high consumption of snack of schoolchildren in accordance with research Padmiari (2004) found that 75\% energy intake in elementary school children in Denpasar comes from food snacks and the remaining $25 \%$ comes from the main food (rice, side dishes, and vegetables).

Barriers to other diets are an overabundance of a certain kind of food. If there is a positive energy balance that lasts longer than the weight will increase and eventually can occur obesity (WHO, 2000). It is advisable to replace children's snack foods with low energy and high fiber foods such as fruits and vegetables. Increased consumption of fruits and vegetables and the reduction of foods high in fat and sugar can reduce the prevalence of obesity (Epstein et al., 2001).

Obese children tend to be lazy to move, get tired, and short of breath during exercise. Obstacles to physical activity are also felt in school, because of the narrow yard and no sports field. Children who lack physical activity show a strong relationship with weight gain (Cooper et al., 2003). Fisher et al. (2006) found that 19\% of children who spent more than 2 hours per day watching television or in front of the screen were overweight.

Setting a healthy diet is done by reducing intake. But parents are not entirely restrictive because the children's considerations are still in its infancy. In obese children and overweight pre-puberty, there may be no need to lose weight, but weight gain should be slowed or stopped temporarily through lifestyle changes such that BMI falls as the child grows taller (Moore, 2013).

Obesity prevention efforts are very necessary. Implementation of the community-based program can be done in school and family environment. Schools are the best settings for childhood obesity interventions because of children from labeling eating and physical activity habits at a young age. School-based interventions focused on childhood obesity prevention must target enhancement of physical activity and healthy nutrition in order to decrease BMI. In changing physical activity behaviors, increasing the duration and types of different activities are important aspects. Increasing fruit and vegetable intake and reducing the intake of sweetened drinks is of critical importance in changing nutrition behaviors. As these studies demonstrate, parental participation plays an important role in school-based interventions. It is essential to involve parents in all school-based interventions for childhood obesity prevention (Almarzooqi \& Nagy, 2011).

On the other hand also developed a family-based program to overweight children. However, some programs incorporate a theoretical framework for studying the family system approach in relation to changes in child health behavior (Kitzman-ulrich, Worth, Wilson, \& Fairchild, 2010). Family-based intervention is a program that targets parents and children in creating a healthy lifestyle, which is generally difficult because families are faced with obesogenic food environments and have sedentary behavior. Interventions that focus on improving overall family health in an ethical and effective way to reduce obesity (Perryman, 2011).

\section{Conclusion}

We have explored the main individual and environmental barriers which influence healthy lifestyles in childhood. Among individual barriers, the influence of priority of studying seems to be unique in our population.

Findings of the current study may help to provide a realistic perspective of the current situation and in designing of future programs for weight control in childhoods:

1. Perception of informants about healthy children is the ideal weight according to age, able to move normally, able to interact socially, and good communication.

2. Perceptions of obesity susceptibility are the wrong diet such as overeating, joy in one type of food and dislike of other foodstuffs, less physical activity and sedentary behavior

3. Healthy obstacles in obese children include excessive eating behavior, difficulty controlling healthy eating behaviors, excessive use of HP gadgets, computer play, and television viewing,

Suiraoka, I. P., Duarsa, D. P. P., Wirawan, I. D. N., \& Bakta, I. M. (2017). Perception of parents, teachers, and nutritionist on childhood obesity and barriers to healthy behavior: a phenomenological study. International Journal of Health Sciences, 1(2), 1-11. https://doi.org/10.21744/ijhs.v1i2.25 
have not found the appeal of exercise and the psychological aspects affecting diet and physical activity.

4. Prevention of childhood obesity includes eating time restrictions, reducing high carbohydrate foods, school canteen cultivation, increasing physical activity of children.

\section{Recommendation}

An obesity prevention program needs to be developed in children by taking into account individual aspects, overcoming environmental barriers and nutrition building in the family and school environment.

\section{Acknowledgement}

The authors would like to thank all participants who made this study possible.

\section{References}

Agarwal, R., Jain, P., Ghosh, M. S., \& Parihar, K. S. (2017). Importance of Primary Health Care in the Society. International Journal of Health Sciences (IJHS), 1(1), 6-11.

Agency for Health Research and Development. (2008). Basic Health Research (RISKESDAS) 2007. National Report 2007. Jakarta. Http://doi.org/1 December 2013

Agency for Research and Development. (2010). Basic Health Research (RISKESDAS) in 2010. Jakarta.

Almarzooqi, M. a, \& Nagy, M. C. (2011). Childhood Obesity Intervention Programs?: A Systematic Review. Life Science Journal, 8(4), 45-60.

Amiri, P., Ghofranipour, F., Ahmadi, F., Hosseinpanah, F., Montazeri, A., Jalali-farahani, S., \& Rastegarpour, A. (2011). Barriers to a healthy lifestyle among obese adolescents?: a qualitative study from Iran. Int J Public Health, 56, 181-189. http://doi.org/10.1007/s00038-010-0119-6

Baker, J. L., Olsen, L. W., \& Sorensen, T. I. A. (2007). Childhood Body-Mass Index and the Risk of Coronary Heart Disease in Adulthood. The New England Journal of Medicine, 357(23), 2329-2337.

Billaiya, R., Jain, A., Agarwal, R., \& Jain, P. (2017). Introduction about Child Health Status in India International Journal of Health Sciences (IJHS), 1(1), 12-22.

Cooper, A., Page, A., Foster, L., \& Qahwaji, D. (2003). Commuting to Scholl: Are Children Who Walk More Physically Active. Am J Prev Med, 25(4), 273-276.

Eka Padmiari, I. (2002). Prevalence of Obesity and Fast Food Consumption as Risk Factors Obesity Occurrence in Elementary School Children in Denpasar City. Gadjah Mada University.

Fisher, L., Fraser, J., \& Alexander, C. (2006). Caregivers Inability to Identify Childhood Adiposity: a Crosssectional Survey of Rural Children and Their Caregivers Attitudes. Australian Journal of Rural Health, $14(2), 56-61$.

Heird, W. C. (2002). Parental feeding behavior and children's fat mass 1, 2. American Journal of Clinical Nutrition, 451-452.

Jain, P. (2017). Effect of Online Education Trend on Quality Management. International Journal of Health Sciences (IJHS), 1(1), 1-5.

Kasiman, S. (2011). Comments Effect of Food On Metabolic Syndrome. J Kardiol Indonesia, 32(1), 24-26.

Kitzman-ulrich, H., Worth, F., Wilson, D. K., \& Fairchild, A. (2010). The integration of a Family Systems Approach for understanding youth obesity, physical activity, and dietary programs. Clinical Child and Family Psychology Review, 13(3), 231-253. http://doi.org/10.1007/s10567-010-0073-0

Malaiya, S., Shrivastava, A., Prasad, G., \& Jain, P. (2017). Impact of Medical Education Trend in Community Development. International Journal of Health Sciences (IJHS), 1(1), 23-27.

Moore, J. (2013). Infant, Child, and Adolescent Nutrition. (S. M. Soetjipto, Ed.). Yogyakarta: Penerbit Pustaka Pelajar.

Nelson, J., Carpenter, K., \& Chiasson, M. (2006). Diet, Activity, and Overweight Among Preschool-Age Children Enrolled in Special Supplemental Nutrition Program for Women, Infants, and Children (WIC). Journal Preventing Chronic Disease, 3(2), 1-17.

Parihar, K. S., Dahiya, R., Billaiya, R., \& Jain, P. (2017). Effect of Nuclear Family in Participation of Activities. International Journal of Health Sciences (IJHS), 1(1), 28-35.

Perryman, M. L. (2011). Ethical Family Interventions for Childhood Obesity (5 No. 8) (Vol. 8).

R \& D Agency. (2010). National Health Research Report (Riskesdas) 2010. Jakarta: Ministry of Health RI.

R \& D Agency. (2013). Basic Health Research Report 2013. Jakarta: Ministry of Health RI. 
Suarjana, N., Karmaya, I. N. M., Satriyasa, B. K., Pangkahila, J. A., \& Astuti, N. P. W. (2017). The Influence of Granting Ngor Eggplant (Solanium Indicum) Extract inhibiting of Spermatogenesis in Mice (Mus Musculus). International Journal of Health Sciences (IJHS), 1(2), 12-19.

Suiraoka, I. P., Duarsa, D. P. P., Wirawan, I. D. N., \& Bakta, I. M. (2017). Perception of Parents, Teachers, and Nutritionist on Childhood Obesity and Barriers to Healthy Behavior: A Phenomenological Study. International Journal of Health Sciences (IJHS), 1(2), 1-11.

Syarif. (2003). Childhood Obesity: Evaluation and Management. In A. S (Ed.), National Obesity Symposium II (pp. 103-139). Surabaya.

WHO. (2000). Obesity?: Preventing and Managing the Global Epidemic. Geneva.

WHO. (2015). Interim Report of the Commission on Ending Childhood Obesity. Geneva.

\section{Biography of Authors}

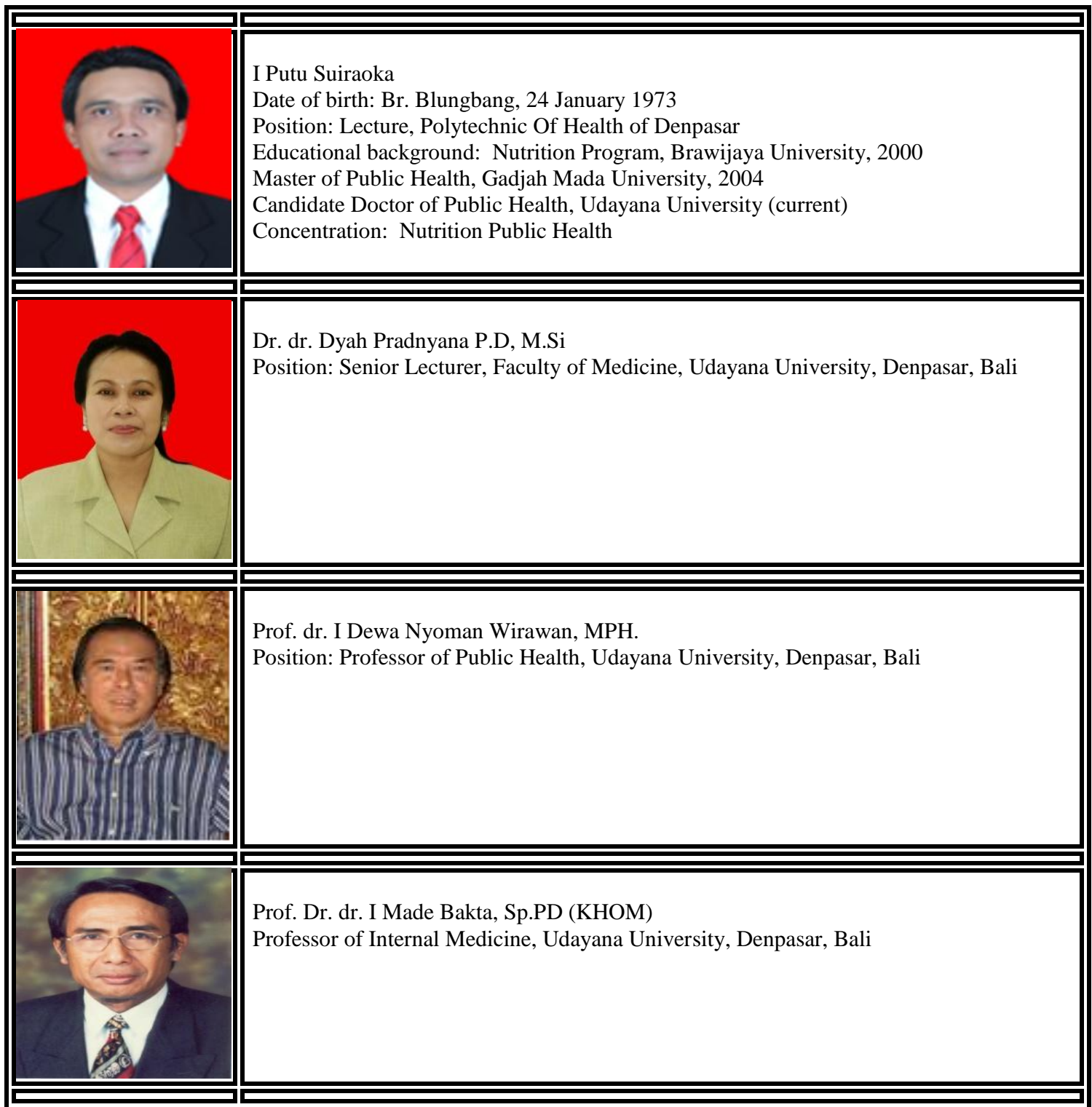

Suiraoka, I. P., Duarsa, D. P. P., Wirawan, I. D. N., \& Bakta, I. M. (2017). Perception of parents, teachers, and nutritionist on childhood obesity and barriers to healthy behavior: a phenomenological study. International Journal of Health Sciences, 1(2), 1-11. https://doi.org/10.21744/ijhs.v1i2.25 